\title{
New Metal Niobate and Silicotitanate Ion Exchangers: Development and Characterization
}

(Project Number: 73748)

\author{
Principal Investigator \\ Yali Su \\ Pacific Northwest National Laboratory \\ P.O. Box 999, MSIN K8-93 \\ Richland, WA 99352 \\ (509) 376-5290 (phone) \\ (509) 376-5106 (fax) \\ ya.su@pnl.gov
}

\section{Co-Investigators}

Tina M. Nenoff

Sandia National Laboratories

P.O. Box 5800, MS 0710

Albuquerque, NM 87185-0709

(505) 844-0340 (phone)

(505) 845-9500 (fax)

tmnenof@sandia.gov

Alexandra Navrotsky

University of California, Davis

Department of Chemical Engineering and Materials Science

One Shields Avenue

Davis, CA 95616-8779

(530) 752-3292 (phone)

(530) 752-9307 (fax)

anavrotsky@ucdavis.edu

\section{Contributors}

M. L. Balmer*, Liyu Li, and Jim Young (PNNL)

May Nyman (SNL)

Hongwu Xu (UC Davis)

*Current address: Caterpillar Inc. Peoria, IL 61656-1875 


\section{Research Objective}

This project is a continuing EMSP project entitled "New Silicotitanate Waste Forms: Development and Characterization." In our original study, the phase selection and chemical durability of silicotitanates (including commercially available IE-911) as a function of temperature (500 to $1000^{\circ} \mathrm{C}$ ) was fully characterized by a combination of techniques including XRD, TEM, SEM, NMR, Raman spectroscopy, XAFS, XANES, and by thermodynamic studies. In addition, work on this program led to new discoveries not anticipated in the originally proposed research. Of particular importance was the discovery of a new ion exchange material that is selective for divalent cations under extreme conditions (e.g., acid solutions, competing cations), thus providing an alternative for removing $\mathrm{Sr}$ from mixed wastes. This material is converted easily by high-temperature, in situ heat treatment into a perovskite phase, which is also a major component of Synroc, a titanate ceramic waste form used for sequestration of high-level waste (HLW) from reprocessed, spent nuclear fuel.

This renewal project is based on the current needs in separation of cesium and strontium and the results obtained from our previous EMSP work. The purpose of this project is to deliver pertinent information that can be used to make rational decisions on selection of separation processes for cesium, strontium, and actinides. The objectives of this project are

1. to establish the structure/property relationship between inorganic ion exchanger materials and their ability to selectively separate divalent cations under extreme operating conditions - This includes optimizing stoichiometry, synthesis, and pretreatment conditions for metal niobate and silicotitanate ion exchangers for maximum strontium and actinide-surrogate selectivity.

2. to fully characterize the phase relationships, structures, and thermodynamic and kinetic stabilities of these new phases and their related condensed phases (as potential ceramic waste forms)

3. to understand the chemical and thermodynamic stabilities of silicotitanate ion exchangers based on an in-depth comprehension of local bonding configurations and thermochemistry

4. to apply fundamental understanding to tailoring an ion exchanger that is ideally suited for a DOE needs and therefore has the potential for short-term deployment in the DOE complex.

\section{Research Progress and Implications}

This report summarizes progress after 7 months of a 3-year project. Components of this report include 1) understanding the structural property relationship of new silicotitanates and niobate based ion exchangers and their related condensed phases (as potential ceramic waste forms); 2) investigating low temperature thermal and chemical stabilities of the CST when CST is 
contacted with SRS waste simulant; 3) determining the enthalpies of formation of new silicotitanates and niobate based ion exchangers and their related compounds by high temperature oxide melt solution calorimetry and 4) evaluating radiation stability of promising CST waste forms and their individual phases.

\section{Structure/Property Relationship Studies}

\section{Sandia Octahedral Molecular Sieves (SOMS)}

The SOMS phases are synthesized by hydrothermal treatment of sol mixtures containing water, sodium hydroxide, and hydrolyzed metal (Nb, Ti, $\mathrm{Zr}$ ) alkoxides. A combination of analytical and spectroscopic data (DTA-TGA, ICP-AES, ${ }^{1} \mathrm{H}$ solid-state MAS NMR) led us to a welldefined composition of $\mathrm{Na}_{2} \mathrm{Nb}_{2-x} \mathrm{Ti}_{x} \mathrm{O}_{6-x}(\mathrm{OH})_{x} \cdot \mathrm{H}_{2} \mathrm{O}(x=0.4)$ for SOMS-1. This composition gave a satisfactory crystallographic solution with a discrepancy index of $\mathrm{R}_{1}=6.29 \%$ for the single crystal structure determination. To ensure the structure determination from the twinned crystal was representative of the bulk SOMS-1 sample, synchrotron x-ray powder diffraction data were collected and modeled by the Rietveld method. The excellent agreement obtained indicated that indeed the models derived from the twinned crystal and powder data are equivalent.

Our collaborators at SUNY-Stony Brook (J. Parise and colleagues) determined the structure of SOMS-1, which is shown in Figure 1. In this chemically constrained model, 3.2Ti and $12.8 \mathrm{Nb}$ atoms per unit cell are distributed randomly over two crystallographically distinct octahedral sites. The octahedrally coordinated $\mathrm{Na} 1$ and $\mathrm{Na} 2$ sites and the square planar $\mathrm{Na} 3$ site are fully occupied, a finding that is consistent with the 5:1:4 $\mathrm{Na}: \mathrm{Ti}: \mathrm{Nb}$ ratio observed by chemical analysis (ICP-AES). The geometry of the Na3 site is distorted by displacements away from the square planar position in the [010] direction, giving rise to 50\% occupied sites $0.52 \AA$ above and below the plane of the oxygen atoms. Although such coordination is unusual for $\mathrm{Na}^{+}$, it is not unprecedented and is likely a compromise to the restricted coordination geometry provided by the framework. The ${ }^{23} \mathrm{Na}$ MAS NMR spectrum of SOMS- 1 confirmed two Na geometries in a 3:1 population ratio (octahedral:distorted square planar) at $-8 \pm 1 \mathrm{ppm}$ (octahedral) and $-11 \pm$ 2 ppm (distorted square planar), respectively. (Dr. M. S. Maxwell at Lawrence Livermore National Laboratory performed the NMR research.)

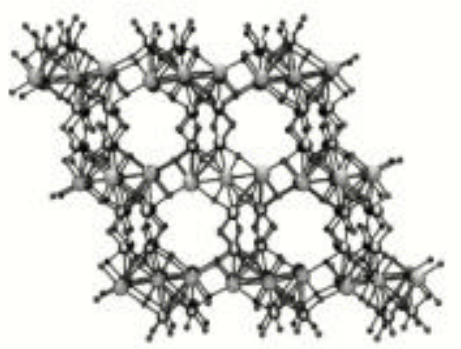

Figure 1. SOMS-1 Framework with Occluded Na+ and Water Molecules Excluded from Channels for Ease of Viewing 
The SOMS phases exhibit ion-exchange selectivity for divalent cations over monovalent cations. The distribution coefficients $\left(\mathrm{K}_{\mathrm{d}}\right)$ for a variety of industrial metals, alkali metals, and alkaline earth metals on SOS- 1 are summarized in Table 1. The divalent transition metals, $\mathrm{Ba}^{2+}$ and $\mathrm{Sr}^{2+}$, are completely removed from solution by SOMS-1. The selectivity of SOMS-1 for the alkali metals is extremely low when compared to its selectivity for alkaline earth metals. Our results indicate that the SOMS phases could be used for applications such as 1) removal of radioactive

${ }^{90} \mathrm{Sr}$ from Na-rich wastes or contaminated groundwater or soils containing natural abundance of $\mathrm{Mg}$ and $\mathrm{Ca}$ and 2) removal of divalent metals from industrial waste streams.

Table 1. Selectivity $\left(\mathrm{K}_{\mathrm{d}}\right)$ of Metals on SOMS-1

\begin{tabular}{|c|c|c|c|c|c|}
\hline Ion & $\overline{\mathrm{K}_{\mathrm{d}}(\mathrm{ml} / \mathrm{g})}$ & $\overline{\text { Ion }}$ & $\mathrm{K}_{\mathrm{d}}(\mathrm{ml} / \mathrm{g})$ & Ion & $\overline{\mathrm{K}_{\mathrm{d}}(\mathrm{ml} / \mathrm{g})}$ \\
\hline$\overline{\mathrm{Ba}^{2+}}$ & 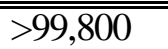 & $\mathrm{Cs}^{+}$ & 150 & $\overline{\mathrm{Pb}^{2+}}$ & 666,497 \\
\hline $\mathrm{Sr}^{2+}$ & $>99,800$ & $\mathrm{~K}^{+}$ & 95 & $\mathrm{Co}^{2+}$ & $>99,800$ \\
\hline $\mathrm{Ca}^{2+}$ & 2,300 & $\mathrm{Li}^{+}$ & 8 & $\mathrm{Ni}^{2+}$ & $>99,800$ \\
\hline $\mathrm{Mg}^{2+}$ & 226 & & & $\mathrm{Zn}^{2+}$ & $>99,800$ \\
\hline & & & & $\mathrm{Cd}^{2+}$ & $>99,800$ \\
\hline
\end{tabular}

The DTA-TGA analysis of SOMS-1 with $10 \%$ of $\mathrm{Na}^{+}$exchanged for $\mathrm{Sr}^{2+}$ shows a weight loss in the temperature range from 100 to $300^{\circ} \mathrm{C}$. This loss corresponds to dehydration (calc. $7.6 \mathrm{wt} \%$, obs. $7.5 \mathrm{wt} \%$ ) followed by structure collapse to an amorphous state as observed by x-ray diffraction. The exothermic transition at $550^{\circ} \mathrm{C}$ is associated with conversion to a perovskite form. Perovskite (titanate-based) is a major component in the well-known SYNROC ceramic waste form for high level radioactive waste storage and, thus, is a reliable commodity for stability in radioactive fields and in repository conditions. Micrographs of the $\mathrm{Sr}^{2+}$-loaded SOMS- 1 and the perovskite reveal that this phase change takes place with remarkable morphology preservation, which indicates that remobilization of the strontium during heating is improbable.

Crystallographic structure refinement of variable $\mathrm{Ti} / \mathrm{Zr}$ concentration SOMS were carried out in collaboration with J. Parise's group at SUNY-Stony Brook. Data shows a slight volume increase when compared to SOMS-1, as is expected since SOMS- 1 has a $20 \%$ substitution of Ti on the $\mathrm{Nb}$ site, and this composition has almost no substitution on the $\mathrm{Nb}$ site: $\mathrm{Zr}_{0.016} \mathrm{Nb}_{0.984}(1.6 \% \mathrm{Zr}-$ SOMS), $R_{\text {Bragg }}=9.66 \%, V=1291.5 \AA^{3} \quad, a=17.038 \AA, b=5.031 \AA, c=16.488 \AA, \beta=113.97^{\circ}$ as compared to SOMS-1 (20\%-TiSOMS) V=1282.6 $\AA^{3} \quad, a=16.939 \AA, b=5.033 \AA, c=16.466 \AA$, $\beta=114.00^{\circ}$.

\section{Ti-Substituted Pollucite, $\mathrm{CsTi}_{x} \mathrm{Al}_{1-\mathrm{x}} \mathrm{Si}_{2} \mathrm{O}_{6+\mathrm{x} / 2}$}

The compositional series $\mathrm{CsTi}_{\mathrm{x}} \mathrm{Al}_{1-\mathrm{x}} \mathrm{Si}_{2} \mathrm{O}_{6+\mathrm{x} / 2}, 0 \quad \mathrm{x} \quad 1$, was synthesized by sol-gel method and was further investigated using $\mathrm{x}$-ray absorption and Raman spectroscopy at PNNL. The data indicate the formation of $\mathrm{TiO}_{5}$ edge-sharing polyhedra at relatively low Ti concentrations $(\mathrm{x}=0.3)$. The presence of $\mathrm{TiO}_{5}$ polyhedra in the compositional series is evident from the intensity and energy value of characteristic pre-edge features in the near-edge structure of the x-ray absorption spectra (XANES), as shown in Figure 2. The edge-sharing geometry of the $\mathrm{TiO}_{5}$ polyhedra is 
determined by the analysis of the extended $x$-ray absorption fine structure (EXAFS), which indicates short (3.0 $\mathrm{A})$ Ti-Ti interatomic distances. The appearance of features in the Raman spectra at 645 and $717 \mathrm{~cm}^{-1}$, as shown in Figure 3, also supports the existence of edge-sharing Ti polyhedra at low levels of Ti substitution. The EXAFS and Raman results suggest a nonrandom pairing of $\mathrm{TiO}_{5}$ polyhedra on symmetrically equivalent sites and the formation of edge-sharing relationship between adjacent $\mathrm{TiO}_{5}$ polyhedra. The formation of an edge-sharing relationship between neighboring $\mathrm{TiO}_{5}$ Polyhedra is an unusual occurrence especially in framework aluminosilicates.

Observations by XAS that edge-sharing Ti configurations exist over the compositional range $0.3<\mathrm{x}<1$ may be useful in explaining the deviations from ideal mixing in the enthalpies of mixing and heats of formation that were observed at UC Davis over this same compositional region. That is, there is a configurational constraint imposed by the requirement that the $\mathrm{Ti}$ atoms are paired. In addition, local ordering on the symmetrically equivalent $\mathrm{Si}, \mathrm{Ti}, \mathrm{Al}$ site in the cubic structure is likely to result from both the requisite Ti pairing and the avoidance of $\mathrm{Ti}-\mathrm{O}-\mathrm{Al}$ and $\mathrm{Al}-\mathrm{O}-\mathrm{Al}$ bonding configurations.

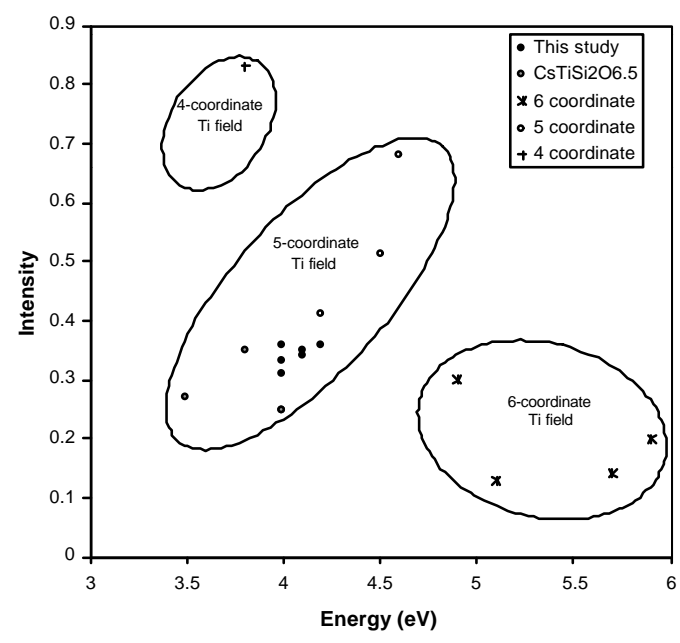

Figure 2. Plot of the energy position of the A2 pre-edge features versus intensity separates $\mathrm{Ti}$ bearing minerals into 4-, 5-, and 6-coordinate $\mathrm{Ti}$ fields. The $\mathrm{CsAl}_{1}{ }_{\mathrm{x}} \mathrm{Ti}_{\mathrm{x}} \mathrm{Si}_{2} \mathrm{O}_{6+\mathrm{x} / 2}$ samples studied here all fall within the 5-coordinate Ti field. The Ti samples from our earlier study are also plotted.

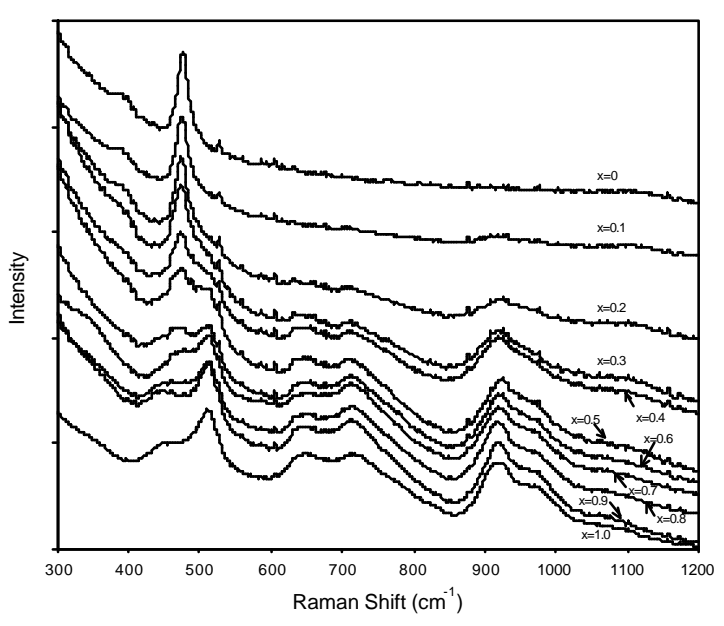

Figure 3. Raman spectra of the compositional series $\mathrm{CsAl}_{1} \quad \mathrm{Ti}_{\mathrm{x}} \mathrm{Si}_{2} \mathrm{O}_{6+\mathrm{x} / 2}$ where $0<\mathrm{x}<1$. As the Ti content increases the intensity of the $474 \mathrm{~cm}^{-1}$ mode, which is characteristic of the $\mathrm{Si}-\mathrm{O}$ bonds in $\mathrm{CsAlSi}_{2} \mathrm{O}_{6}$, decreases. The Raman features at 645 and $717 \mathrm{~cm}^{-1}$ are indicative of an edge-sharing relationship between Ti-polyhedra.

\section{SNL-A Analogs; Cc-A2TiSi6 ${ }_{15} ; A=K, R b, C s$}

Alkali silicotitanate ternary phases have been studied for a wide variety of applications including selective ion exchange and ceramic materials for storing nuclear waste. We present the synthesis and characterization of $\mathrm{Rb}_{2} \mathrm{TiSi}_{6} \mathrm{O}_{15}$ and $\mathrm{K}_{2} \mathrm{TiSi}_{6} \mathrm{O}_{15}$, which are structural analogs of the extremely thermodynamically stable $C c-\mathrm{Cs}_{2} \mathrm{TiSi}_{6} \mathrm{O}_{15}$ phase (also known as SNL-A) produced at Sandia National Laboratories. The $\mathrm{Rb}$-analog is the first reported ternary oxide, rubidium silicotitanate 
phase. Both phases were synthesized in a pure form by hydrothermal treatment of oxide precursor mixtures seeded with SNL-A. They could not be synthesized without addition of the seed. Analysis included $\mathrm{x}$-ray powder diffraction, SEM/EDS, thermal analyses, and ${ }^{29} \mathrm{Si}$ MAS NMR.

In addition to their potential application as durable ceramic waste form materials, these new isostructural phases have presented the opportunity to relate phase stability to properties such as framework structure and chemical composition to structural complexity, ternary and quaternary oxide phases.

Rietveld refinement gave good structural models in the Cc space group with the following unit cell parameters: (Rb-analog) $\mathrm{V}=1357.9 \AA^{3}, a=12.736(2) \AA, b=7.3392(3) \AA, c=15.061(3) \AA$, $\beta=105.29(2)^{\circ}$; (K-analog) $\mathrm{V}=1318.5 \AA^{3}, a=12.570$ (2) $\AA, b=7.2534(3) \AA, c=15.082(3) \AA, \beta$ $=106.49(3)^{\circ}$. Direct correlation was observed between alkali radius $(\mathrm{Cs}>\mathrm{Rb}>\mathrm{K})$ with 1$)$ melting temperature and 2) unit cell parameters including volume $\left(\AA^{3}\right), a$-axis and $b$-axis $(\AA)$. The increasing $a$ - and $b$-axes with increasing alkali radius correlate with a "relaxation" of the silicate layer folds, which also is accompanied by an increase in average $\mathrm{SiO}-\mathrm{Si}$ bond angle.

\section{Chemical and Thermal Stabilities of CST}

An inorganic ion exchanger based on crystalline silicotitanate (CST), IONSIV ${ }^{\circledR}$ IE-911 ion exchanger (UOP LLC, Des Plaines, Illinois) currently is being considered for Cs separation at the Savannah River Site (SRS). While the performance of this ion exchanger has been well characterized under normal operating conditions, the stability of the material at slightly elevated temperatures, such as those that may occur in a process upset, is the subject of current evaluations at PNNL.

IE-911 was exposed to waste simulant at $55^{\circ} \mathrm{C}$ and $80^{\circ} \mathrm{C}$ for durations ranging from 1 to 60 days to determine if irreversible desorption of Cs from IE-911 occurs and, if so, the cause of the desorption and the time/temperature profiles over which it occurs. High Cs loading, high simulant/IE-911 ratio, and high-temperature heat treatment could cause irreversible Cs desorption. SEM results showed that a crystalline sodium aluminosilicate (nitrate cancrinite) phase precipitated on the surface of IE-911 shortly after exposure to simulant both at $55^{\circ} \mathrm{C}$ and at $80^{\circ} \mathrm{C}$. The morphology of the coating depends on the heat-treatment temperature, heat-treatment time, IE-911-to-simulant ratio, and simulant composition. IE-911 is not the major Si source for the aluminosilicate precipitation. The coating should not be the major reason for the irreversible $\mathrm{Cs}$ desorption because it was found on the surface of almost all the heat-treated IE-911 samples. Cancrinite-type aluminosilicate has large size openings in its structure so that Cs should be able to diffuse through these pores to IE-911 when the temperature was lowered. The mechanism for the irreversible Cs desorption is still under investigation. 


\section{Thermodynamic Studies Using High-Temperature Reaction Calorimetry}

\section{Crystal Chemistry and Energetics of Ti-Substituted Perovskites}

Using the sol-gel and solid-state sintering methods, two series of Ti-substituted niobate perovskites were synthesized at PNNL: 1) $\mathrm{NaTi}_{\mathrm{x}} \mathrm{Nb}_{1-\mathrm{x}} \mathrm{O}_{3-0.5 \mathrm{x}}(0 \leq \mathrm{x} \leq 0.3)\left(\mathrm{Ti}^{4+}+1 / 2 \mathrm{O}^{2-} \rightarrow\right.$ $\left.\mathrm{Nb}^{5+}\right)$; and 2) $(\mathrm{SrTi})_{\mathrm{x}}(\mathrm{NaNb})_{1-\mathrm{x}} \mathrm{O}_{4}(0 \leq \mathrm{x} \leq 1)\left(\mathrm{Sr}^{2+}+\mathrm{Ti}^{4+} \rightarrow \mathrm{Na}^{+}+\mathrm{Nb}^{5+}\right)$.

Rietveld analysis of XRD data at UC-Davis shows that the symmetry of the structure in both series systematically increases with increasing Ti content (orthorhombic $\rightarrow$ tetragonal $\rightarrow$ cubic), as is consistent with the fact that the tolerance factor of perovskite becomes closer to unity as the Ti content increases. These compositionally driven phase transitions are analogous to those that occur in $\mathrm{NaNbO}_{3}$ at elevated temperatures. To further reveal the structural characteristics, such as the $\mathrm{O}$ vacancy positions in the first series, a set of high-resolution neutron diffraction data has been collected at Los Alamos National Laboratory, and detailed structure analysis using the Rietveld method is in process at UC-Davis.

The enthalpies of drop solution in molten $3 \mathrm{Na}_{2} \mathrm{O} \cdot 4 \mathrm{MoO}_{3}$ at $974 \mathrm{~K}$ were measured at UC-Davis by high-temperature reaction calorimetry, and the enthalpies of formation from constituent oxides have been determined using appropriate thermochemical cycles. With increasing Ti content, the enthalpy of formation in both series becomes less exothermic, implying a destabilizing effect of the substitution $\mathrm{Ti}^{4+}+1 / 2 \mathrm{O}^{2-} \rightarrow \mathrm{Nb}^{5+}$ and $\mathrm{Sr}^{2+}+\mathrm{Ti}^{4+} \rightarrow \mathrm{Na}^{+}+\mathrm{Nb}^{5+}$ on the perovskite structure (Figure 4). Further, in contrast to the trend in lattice parameters corresponding to the compositionally driven transitions, the enthalpic variation with composition is approximately linear. This behavior suggests that the enthalpies of these transitions are rather small, as is consistent with the small enthalpies for the transitions in $\mathrm{NaNbO}_{3}$ at high temperature.
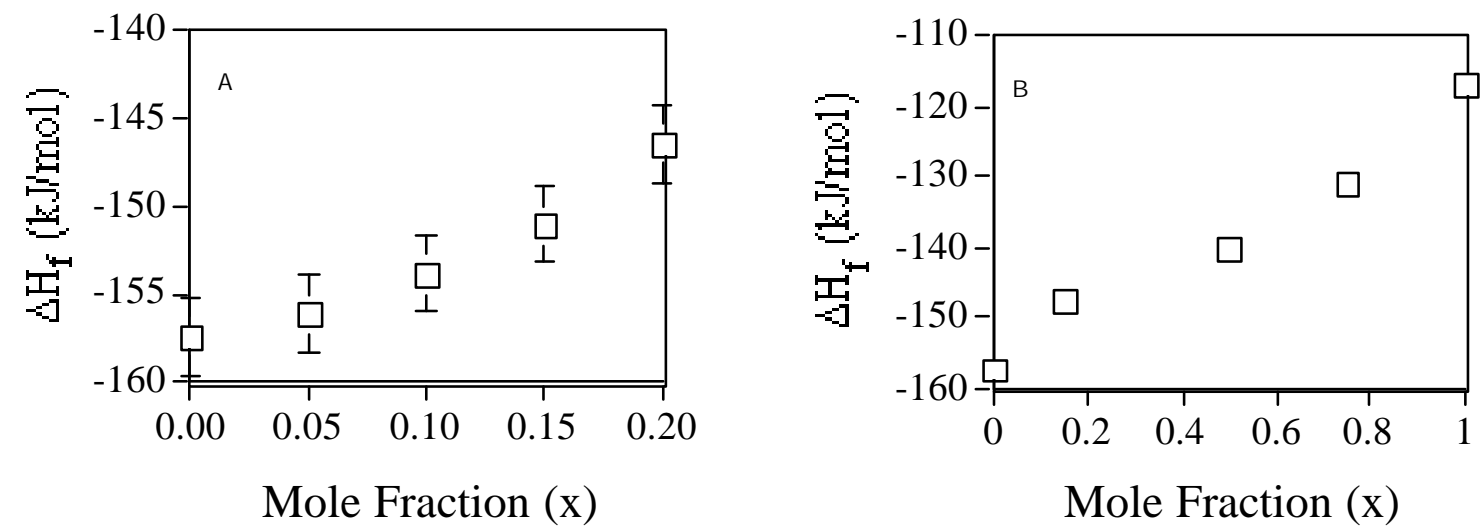

Figure 4. Variation in the Enthalpies of Formation of $\mathrm{A}) \mathrm{NaTi}_{\mathrm{x}} \mathrm{Nb}_{1-\mathrm{x}} \mathrm{O}_{3-0.5 \mathrm{x}}$ and B) $(\mathrm{SrTi})_{\mathrm{x}}(\mathrm{NaNb})_{1-\mathrm{x}} \mathrm{O}_{4}$ from the Oxides as a Function of Composition 


\section{Energetics of $\mathrm{Na}_{5} \mathrm{TiNb}_{4} \mathrm{O}_{12} \cdot \mathrm{H}_{2} \mathrm{O}$ lon Exchanger}

Using the hydrothermal method, researchers at Sandia synthesized a series of octahedral molecular sieves that have high selectivity for radioactive $\mathrm{Sr}^{2+}$. Upon heating at high temperatures, these microporous ion exchangers convert to the thermodynamically stable and chemically durable dense perovskite phases. From drop solution calorimetry in sodium molybdate solvent at $974 \mathrm{~K}$, the enthalpy of formation from the oxides of the exchanger $\mathrm{Na}_{5} \mathrm{TiNb}_{4} \mathrm{O}_{12} \cdot \mathrm{H}_{2} \mathrm{O}$ and that of its corresponding perovskite phase $\mathrm{Na}_{5} \mathrm{TiNb}_{4} \mathrm{O}_{14.5}$ have been determined to be $-702.5 \pm 12.7$ and $-709.2 \pm 11.6 \mathrm{~kJ} / \mathrm{mol}$, respectively. Similar calorimetric measurements will be conducted at UC-Davis for Sr-containing phases. The goal of this study is to gain a fundamental understanding of the Na-Sr exchange energetics and the thermodynamics and kinetics of the potential waste forms.

\section{Radiation Stability Studies}

The thermally converted durable waste forms of Cs-loaded IE-911 have been developed at PNNL. The radiation effect on the thermally treated IE911 sample was investigated using JEOL 2010F transmission electron microscope by collaborators (B. Gu, L. Wang, and R. Ewing) at the University of Michigan. The operating voltage of the microscope was $200 \mathrm{kV}$. Multiple phases were identified based on chemical analysis with EDS and selected area diffraction patterns.

Electron beam irradiation has been performed on the two major phases in IE911 sample. As is indicated in the previous study, most of $\mathrm{Cs}$ appears to be in a $\mathrm{Cs}_{2} \mathrm{ZrSi}_{3} \mathrm{O}_{9}$ phase. The irradiation of this phase with a total electron dose of $2.3 \mathrm{E}+22$ electron $/ \mathrm{cm}^{2}$ did not cause any change in the diffraction pattern, thus indicating that the phase is quite stable under high dose of ionizing irradiation. Similar electron dose did not cause amorphization of the $\mathrm{Na}_{2} \mathrm{Ti}_{6} \mathrm{O}_{13}$ phase; however, the changes in the intensity of certain diffraction patterns imply that cation disordering may have occurred during the irradiation (Figure 5).
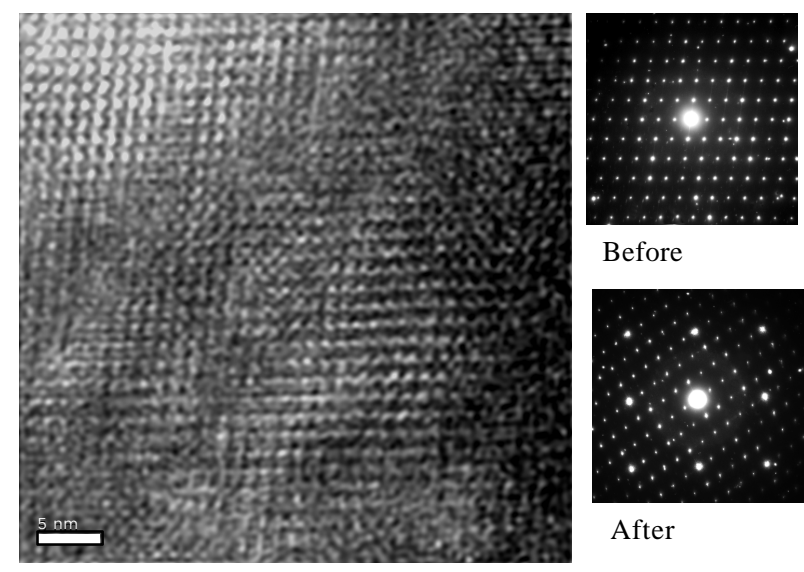

Before

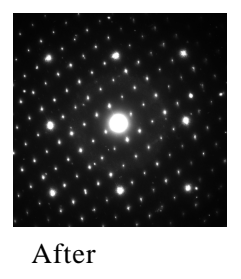

$\mathrm{Na}_{2} \mathrm{Ti}_{6} \mathrm{O}_{13}$ high resolution TEM

Figure 5. High Resolution TEM Images of $\mathrm{Na}_{2} \mathrm{Ti}_{6} \mathrm{O}_{13}$ and Electron Diffraction Patterns of Before and After $200 \mathrm{KeV}$ Electron Irradiation $\left(2.2 \mathrm{E}+22 \mathrm{e}^{-} / \mathrm{cm}^{2}\right)$ 


\section{Planned Activities}

Future work will concentrate on studying ionic potential versus $\mathrm{K}_{\mathrm{d}}$ (ion selectivity) to better understand divalent cation selectivity of $\mathrm{Na} / \mathrm{Nb} / \mathrm{Ti} / \mathrm{O}$ phases, determining precise atomic positions (particularly oxygen positions) of $\mathrm{A}_{2} \mathrm{TiSi}_{6} \mathrm{O}_{15}(\mathrm{~A}=\mathrm{K}, \mathrm{Rb}, \mathrm{Cs})$ by neutron diffraction to better understand changes in structural parameters with change in alkali cation, and synthesizing $(\mathrm{Cs}, \mathrm{Ba}) / \mathrm{Si} / \mathrm{Ti}$ and $(\mathrm{Cs}, \mathrm{Ba}) / \mathrm{Zr} / \mathrm{Si}$ compounds to understand the stability of Cs-containing compounds that radioactively decay to $\mathrm{Ba}$. In addition, the heat of formation of these compounds will be measured.

\section{Information Access}

\section{Publications}

Balmer ML, DE McCready, and Y Su. "Cubic-to-tetragonal phase transition in ti-substituted pollucite." Submitted to Journal of the American Ceramic Society.

Balmer ML, Y Su, H Xu, ER Bitten, DE McCready, and A Navrotsky. 2001. "Synthesis, structure determination and aqueous durability of $\mathrm{Cs}_{2} \mathrm{ZrSi}_{3} \mathrm{O}_{9}$." Journal of the American Ceramic Society 84:153-160.

Ness N, Y Su, and ML Balmer. 2001. "Evidence of edge-sharing $\mathrm{TiO}_{5}$ polyhedra in Tisubstituted pollucite, $\mathrm{CsTi}_{\mathrm{x}} \mathrm{Al}_{1-\mathrm{x}} \mathrm{Si}_{2} \mathrm{O}_{6+\mathrm{x} / 2}$." Journal of Physical Chemistry $B$ (in press).

Nyman M, A Tripathi, JB Parise, RS Maxwell, WTA Harrison, and TM Nenoff. 2001. "A new family of octahedral molecular sieves: Sodium Ti/Zr(IV) niobates." J. Amer. Chem. Soc. 123(7):1529-1530.

Nyman M, BX Gu, LM Wang, RC Ewing, and TM Nenoff. 2000. "Synthesis and characterization of a new microporous cesium silicotitanate (SNL-B) molecular sieve." Microporous and Mesoporous Materials 40:1-3, 115.

Nyman M, F Bonhomme, DM Teter, RS Maxwell, BX Gu, L Wang, RC Ewing, and TM Nenoff. 2000. "Integrated experimental and computational methods for structure determination and characterization of a new, highly stable cesium silicotitanate phase, Cs2TiSi6O15 (SNL-A)." Chem. Mater. 12:3449.

Nyman M, F Bonhomme, TM Nenoff. "First Rb-silicotitanate phase and its K-structural analog: New members of the SNL-A family (Cc-A2TiSi6O15; A=K, Rb, Cs)." Chem. Mater 2001, submitted.

$\mathrm{Xu} \mathrm{H}$, A Navrotsky, MD Nyman, and TM Nenoff. 2000. "Thermochemistry of microporous silicotitanate phases in the $\mathrm{Na}_{2} \mathrm{O}-\mathrm{Cs}_{2} \mathrm{O}-\mathrm{SiO}_{2}-\mathrm{TiO}_{2}-\mathrm{H}_{2} \mathrm{O}$ system." Journal of Materials Research 15:815-823. 
Xu H, A Navrotsky, ML Balmer, Y Su, and ER Bitten. 2001. "Energetics of substituted pollucites along the $\mathrm{CsAlSi}_{2} \mathrm{O}_{6}-\mathrm{CsTiSi}_{2} \mathrm{O}_{6.5}$ join: A high-temperature calorimetric study." Journal of the American Ceramic Society 84:555-560.

Xu H, Y Zhang, and A Navrotsky. 2001. "Enthalpies of formation of microporous titanosilicates ETS-4 and ETS-10." Microporous and Mesoporous Materials (in press).

\section{General Press Publications}

Tina M. Nenoff was photographed and interviewed for an article upcoming in National Geographic magazine on U.S. nuclear waste legacy research (publication scheduled for summer 2002).

SOMS was featured in Scientific American (web site), DOE Focus magazine, Sandia Lab News, and in numerous newspapers around the United States and in Europe (Associated Press article).

\section{U.S. Patent Submission}

"A New Class of Inorganic Molecular Sieves: Sodium Niobium Metal Oxides." TM Nenoff and M Nyman, July 2000.

\section{Presentations}

Nenoff TM and M Nyman. 2000. "A Novel Class of Niobate-based Molecular Sieves." 16th International Canadian Catalysis Society Meeting, Banff, Alberta, Canada, June 2000.

Nenoff TM, M Nyman, A Tripathi, JB Parise, and RC Ewing. 2000. "SOMS: New Classes of $\mathrm{Na} / \mathrm{Nb} / \mathrm{X} / \mathrm{O}$ microporous and perovskite phases.” 2000 Fall MRS Meeting, Boston, Massachusetts.

Nenoff TM, M Nyman, A Tripathi, JB Parise, WTA Harrison, and RS Maxwell. 2001. "SOMS-Sandia octahedral molecular sieves: A new class of ion exchangers selective for the removal of $\mathrm{Sr}^{2+}$ from waste streams." 13th International Zeolite Conference, Montpelier, France, July 2001.

Nenoff TM, M Nyman, A Tripathi, JB Parise, WTA Harrison, RS Maxwell, and RC Ewing. 2001. "SOMS, new classes of $\mathrm{Na} / \mathrm{Nb} / \mathrm{X} / \mathrm{O}$ microporous and perovskite phases." Solid State Chemistry Gordon Conference, Oxford, United Kingdom, September 2001.

Nenoff TM, M Nyman, A Tripathi, JB Parise, WTA Harrison, RS Maxwell, and RC Ewing. 2001. "SOMS, a new class of molecular sieves with high selectivity for radioactive $\mathrm{Sr}^{+}$." Inorganic Chemistry Gordon Conference, Rhode Island, July 2001. 
Nenoff TM, M Nyman, ML Balmer, Y Su, L Li, A Navrotsky, and H Xu. 2001. "Synthesis and characterization of novel microporous materials (Cs,Na/Si/M/Ti/O)." Tanks Focus Area Midyear Review Meeting, Salt Lake City, Utah, March, 2001.

Su Y, L Li, J Young, and ML Balmer. 2001. "Chemical and thermal stability studies of Csloaded crystalline silicotitanate." 222nd American Chemical Society National Meeting, Chicago, Illinois, August 2001. 